\title{
NERICA Cultivation and its Yield Determinants: The Case of Upland Rice Farmers in Namulonge, Central Uganda
}

\author{
Kisho Miyamoto \\ Japan Overseas Cooperation Volunteer, JICA Uganda Office, P. O. Box 12162, Kampala, Uganda \\ Atsushi Maruyama \\ Chiba University, Matsudo 648, Matsudo City, Chiba 271-8510, Japan \\ Yusuke Haneishi, Shunsuke Matsumoto \& TatsushiTsuboi \\ JICA Expert, JICA Uganda Office, P. O. Box 12162, Kampala, Uganda \\ Godfrey Asea \& Stella Okello \\ National Crops Resources Research Institute, P. O. Box 7084, Kampala, Uganda \\ Michiko Takagaki \& Masao Kikuchi (Corresponding author) \\ Chiba University, Matsudo 648, Matsudo City, Chiba 271-8510, Japan \\ Tel: 81-90-4956-1911 E-mail:m.kikuchi@faculty.chiba-u.jp
}

Received: January 16, 2012 Accepted: February 14, 2012 Online Published: April 20, 2012

doi:10.5539/jas.v4n6p120 URL: http://dx.doi.org/10.5539/jas.v4n6p120

This study was conducted as a research project of NARO-JICA NERICA Promotion Project. The analysis of this study was supported by JSPS Science Research Fund (KAKENHI No.19405046).

\begin{abstract}
This paper examined actual farmers' cultivation practices of NERICA (New Rice for Africa) and the determinants of its yield, based on data obtained from a field survey conducted in central Uganda. NERICA's high yielding potential was realized in farmers' fields. On average, farmers attained yield as high as $3 \mathrm{t} \mathrm{ha}^{-1}$. A high seeding rate, high fertilizer/chemical applications and high laborintensity characterized the upland NERICA cultivation in the study area. The estimation of yield function revealed that the response of rice yield to nitrogen was as high as $46 \mathrm{~kg} \mathrm{ha}^{-1}$ of paddy per $1 \mathrm{~kg} \mathrm{ha}^{-1}$ of nitrogen applied, and that the continuous planting reduced the yield significantly. The large difference in the unit yield between large and small farmers was explained by small farmers' higher input intensities than large farmers', and it is the high labor requirement of NERICA that makes it a pro-smallholder technology.
\end{abstract}

Keywords: Cultivation practice, Nitrogen response, Continuous planting, Labor intensity, Yield function

\section{Introduction}

A decade has passed since NERICA (New Rice for Africa; Oryza sativa $x$ O. sativa $\times$ O. glaberrima) was released from the Africa Rice Center (then West African Rice Development Association (WARDA)). Because of its high-yielding potential, NERICA was expected to bring about a rice Green Revolution in sub-Saharan Africa (WARDA, 2001, 2002; Otsuka \& Karilajan, 2006; Balasubramanian et al., 2007; Kaneda, 2007; Somado et al., 2008) and indeed farmers were enthusiastic to adopt NERICA not only in West Africa where rice is a staple food, but also in East Africa where rice is not a traditional staple crop.

NERICA's mother land in East Africa is the National Crops Resources Research Institute (NaCRRI), Namulonge, Uganda, where research on a series of rice varieties has been conducted under the auspices of JICA, and recently 
under the National Agricultural Research Organization (NARO)-JICA NERICA Promotion Project for its wider adoption by farmers in Uganda and other East African countries, as a principal agent to promote rice Green Revolution in this region. Because of its high yielding nature, versatile adaptation and promotion, NERICA has attracted a lot of attention by researchers and policy makers, and some literature has been accumulated (Kijima et al., 2006, 2008, 2010; Fujiie et al., 2010), including some recent literature that casts doubt over the potential of NERICA (Kijima et al., 2011).

Given the wide diversity of upland farming practices in the region, it is important to conduct as much follow up research as possible to assess the performance of NERICA. Particularly scarce is the information on how farmers cultivate NERICA in their upland fields and how NERICA performs in farmers' field. The purpose of this study is to fill this gap using data collected by a field survey conducted for NERICA farmers around Namulonge in Central Uganda. More specifically, we assess the potential of NERICA through looking into actual farmers' NERICA cultivation practices and the determinants of its yield.

\section{Materials and Methods}

\subsection{Field Survey}

Data used in this study was collected through a field survey conducted from October to November 2010 in two sub-counties around Namulonge interviewing farmers who planted NERICA in the 1st and 2nd seasons of 2009 and 1st season of 2010. The selection of this study area was purposive. Firstly, the study area in Central Uganda is a typical upland area where there are favorable agro-climatic conditions for growing NERICA. Secondly, being near to the center of research on and dissemination of NERICA, farmers in the study area began to adopt it as soon as NaCRRI began NERICA research so that NERICA cultivation is well established for many farmers. The selection of two sample sub-counties, Busukuma and Zirobwe, was also purposive. Though the former is in Wakiso District and the latter in Luwero District, they belong to the same contiguous farming area with a similar history of NERICA cultivation. We interviewed 47 NERICA farmers using a structured questionnaire. The selection of the farmers interviewed was not random sampling in the strict textbook sense, but they were drawn randomly in the sense that we interviewed the farmers randomly whenever they were available from among those who were known to us as NERICA adopters.

\subsection{Methods}

In this paper, we present how farmers cultivate NERICA according to their use of production inputs and what factors determine NERICA yield per unit of land. The presentation of input use is straightforward and no sophisticated statistical method is required except for the t-test for mean differences and the z-test for ratio differences in the sample. In case a monetary value is used, it is expressed in US dollar and Ugandan shilling, using the exchange rate of US\$ $1.00=$ UGX 2,100, the average of the official exchange rate for 2009-2010. The determinants of rice yield are analyzed by estimating yield function of the following form:

$$
\mathrm{Y}=\alpha+\sum_{i}^{k} \beta_{i} X_{i}+\sum_{j}^{m} \gamma_{j} Z_{j}+u
$$

where $\mathrm{Y}=$ rice yield $\left(\mathrm{kg} \mathrm{ha}^{-1}\right), \mathrm{X}_{\mathrm{i}}=\mathrm{i}$-th production input, $\mathrm{Z}_{\mathrm{j}}=$ other explanatory variables, $\mathrm{u}=$ error term and $\alpha, \beta$, $\gamma$ are parameters to be estimated. Throughout the paper, the significance levels for statistical tests are shown by symbols: $* * * * *, *$, and ns stand for $1 \%, 5 \%, 10 \%$ and non-significant, respectively.

\section{Results and Discussion}

\subsection{Study Area and Characteristics of Sample Farmers}

\subsubsection{Study Area}

The study area is in the agro-ecological zone of Lake Victoria Crescent, where undulating topography, in which gentle, wavy slopes with wetland at the shallow valley bottom repeatedly appear, the typical landscape all over Uganda except for the mountainous zones of East and West, covers throughout the zone. The agriculture system in sub-humid Lake Victoria Crescent is the banana-coffee system where plantain banana and coffee (robusta), the former as a main staple crop and the latter as a major cash crop, are grown among other various upland crops such as maize, cassava, and beans. Because of close proximity to the metropolitan area, many farmers in the study area also grow various vegetables and raise such livestock as cow for milk and chicken for eggs. The study area, however, remains predominantly agricultural, with $95 \%$ of households engaging in agriculture (Sako et al., 2010).

The average annual rainfall in the study area is around $1200 \mathrm{~mm}$ and the average temperature is about $22^{\circ} \mathrm{C}$ with 
few fluctuations throughout the year, which provides favorable climatic conditions for growing various upland crops, including upland rice (NaCRRI, undated). The rainfall pattern in the area is a typical bimodal one, with a peak in April - May and another peak in September - October, creating two distinct growing seasons in a year. Although such climatic conditions are 'very suitable' for NERICA growing, rather sharp dry spells with little rain between the two rainy seasons make this region the second best region for growing upland rice, next to some districts in the western part of Uganda. The rainfall in the study period, measured at the Namulonge weather station, was $436 \mathrm{~mm}$ in the first half of $2009,567 \mathrm{~mm}$ in the second half of 2009 and $733 \mathrm{~mm}$ in the first half of 2010. Since rainfall of $400 \mathrm{~mm}$ per season is adequate for growing NERICA (NaCRRI, undated), NERICA farmers received sufficient rain during the study period.

In the study area, as in other areas under the banana-coffee system, rice is not a traditional crop. In the past, the Government of Uganda occasionally attempted, with assistances from foreign countries, to introduce upland rice as one of the upland crops in this system, letting NaCRRI conduct field testing on the feasibility of rice growing, though none of these attempts before the introduction of NERICA was successful. Because a part of the field testing for these rice projects was conducted in farmers' fields around NaCRRI, rice was not a totally unfamiliar crop for some farmers in the area. Except for these farmers, however, rice was utterly exotic crop for almost all farmers in the study area.

\subsubsection{Household Characteristics}

Household characteristics of 47 sample farmers are summarized in Table 1. In this paper, farmers are placed into two groups according to the size of their cultivating area: Large farmer if holding cultivated land area of 2 ha (5 ac) or more and small farmer if holding less than 2 ha. The demarcation size of 2 ha is the average cultivated area of rice farmers in the country (Haneishi et al., 2011b).

The age of household heads of the 47 sample farmers ranged from 26 to 68 with the average of 43 years old and there was no significant difference between large and small farmers. The educational level of household heads, ranging wide from 0 to 25 years, was on average 6.3 years and smallholders tended to have lesser education than large farmers. The existence of female-headed households, such as widowed or separated, is not rare in the study area. Thirteen percent of households in the entire sample fell in this category, but none of them belonged to the large farmer class. The percentage share of heads having non-farm occupationswas significantly higher for large farmers than for small farmers. Similarly, the characteristics related to households' potential to mobilize family labor for NERICA cultivation, i.e., number of household members, and number of members age 10 and older, were significantly larger for large farmers than for small farmers.

The next two rows in Table 1 show household heads' membership in farmers' groups and their attendance to the NERICA training. For these characteristics too, the percentage for large farmers was significantly higher than for small farmers. Large farmers tended to join farmers' groups more than small farmers. The percentage share of farmers, who attended NERICA training in which farmers were taught basic knowledge of NERICA cultivation in a one-day course regularly provided by NaCRRI/JICA, was also higher for large farmers than for small farmers.

The last three rows in the table are household characteristics related to farm land holding and land tenure. On average, the sample farmers held a cultivated land area of 2.7 ha $(6.7 \mathrm{ac})$. The distribution of cultivated land among farmers was highly uneven: Large farmers held on average 6.1 ha $(15.0 \mathrm{ac})$, whereas small farmers'cultivated land area as small as $0.7 \mathrm{ha}(1.8 \mathrm{ac})$. As indicated by the standard deviation, the variation in land holding was still large within the large farmer class: It ranged from 2 ha to as large as 28 ha. On average, the land area planted to rice was $0.34 \mathrm{ha}(0.83 \mathrm{ac})$ for the entire sample, $0.46 \mathrm{ha}(1.15 \mathrm{ac})$ for large farmers and 0.27 ha (0.66) for small farmers. The last row in Table 1 shows that about $30 \%$ of NERICA farmers planted rice on leased area and this percentage was significantly higher for small farmers than for large farmers. This observation suggests the existence of high enthusiasm among farmers to plant NERICA, particularly among smallholders (Haneishi, et al., 2011a).

On average for the entire sample, the NERICA farmers in this study shared similarities in many household characteristics with NERICA farmers in other upland rice growing areas in Central, Western and Northern Uganda as presented by earlier studies (Kijima et al., 2006, 2008, 2011; Fujiie et al., 2010), though few earlier studies presented explicitly the difference in the household characteristics between large and small farmers. For heads' age and education, the size of households, and total land holding, our sample farmers were quite comparable to their counterparts in other areas. Our sample farmers showed a lower level for the percentage of farmers who join some farmers' group/organization. The characteristic of NERICA farmers in the study area most distinctly different from NERICA farmers in other areas was the high incidence of short-term tenancy. 
Many farmers in our study area, in particular tiny-sized small farmers, leased land from other farmers for one or a few seasons with a fixed rent in cash, just for growing NERICA. This tenancy was a spontaneous arrangement between farmers, different from the formal land tenure system in Uganda such as mailo and long-term leasehold systems (Batungi, 2008). The earlier studies are nearly silent about this kind of tenancy arrangement burgeoning with the dissemination of NERICA.

\subsection{NERICA Planting History}

The first time farmers in the study area planted NERICA was 2004 when NaCRRI started systematically promoting NERICA. Among the 47 sample farmers, there were four farmers who tried upland rice before the introduction of NERICA under NaCRRI's upland rice promotion programs in the 1990s. The number of famers who plant NERICA has progressively increased since then; $30 \%$ of farmers adopted NERICA in the first 4 years and $70 \%$ of them in the recent three years.

Table 2 summarizes data on rice yield and varieties planted by the sample farmers in the last 5 years. Rice yield per unit of planted area in the last nine seasons ranged from 2.2 to $3.7 \mathrm{t} \mathrm{ha}^{-1}$. Although yield has been declining in the last three seasons, no significant trend is detected over the nine seasons. The degree of yield fluctuation, measured by coefficient of variation, showed a statistically significant downward trend, though it was still as high as $65 \%$ in the last two seasons. Area planted to rice per farm revealed slight, but significant declines from a 0.4 ha level in earlier years to a 0.3 ha level in recent years, due partly to the fact that relatively more small farmers began NERICA cultivation in recent years. Compared to the national average rice yield reported in the official statistics, which was 1.3-1.5 $\mathrm{tha}^{-1}$ for this period, NERICA yield in the study area was higher by 1 to 1.5 $\mathrm{t} \mathrm{ha}^{-1}$. The NERICA yield of $2.6 \mathrm{tha}^{-1}$ in 2004 for farmers in ten Central and Western districts, including Wakiso, reported by Kijima et al. (2006), is comparable to the yield of our sample farmers, while the NERICA yield of $1.3 \mathrm{t} \mathrm{ha}^{-1}$ in 2008 of farmers in three Northern districts reported by Fujiie et al. (2010) is much lower than ours. Kijima et al. (2006) and Fujiie et al. (2010) both reported that 0.4 ha (1 ac) was the average size of area planted to NERICA per farm, which is also comparable to the average planting size in our study area.

NERICA 4 has been the most popular NERICA variety in the study area (Table 2). In the 20101 st season, more than $90 \%$ of farmers who planted rice adopted this variety. If Suparica, an alias of NERICA 4 , is included, the percentage share of NERICA 4 reaches $95 \%$. In earlier years, relatively more farmers planted unknown non-NERICA upland rice varieties, but in recent years the varieties selected by farmers converged to NERICA 4 . It should be mentioned, however, that some farmers have been trying other rice varieties, such as NERICA 1 and NERICA 10, on experimental scales.

The yield data in Table 2 are rearranged in Table 3 to obtain yield per ha by year and by season, together with rainfall. The t-test reveals that no significant difference is found between years and between seasons. Being cultivated under a rainfed upland condition, rainfall is a critical determinant of NERICA yield. NERICA can be grown comfortably with rainfall of $400 \mathrm{~mm}$ per season, or with $300-400 \mathrm{~mm}$ per season if its distribution synchronizes well to its growing cycle (NaCRRI, undated). Rainfall of $300 \mathrm{~mm}$ or less per season does not sustain the growth of NERICA. From the 2006 1st season to the 2010 1st season none of the season's rainfall in the study area was inadequate for growing NERICA, so that rainfall was not a constraint for farmers to enjoy its average yield as high as 2.7-2.9 $\mathrm{t} \mathrm{ha}^{-1}$.

In the study area, NERICA is planted either continuously or in rotation with other crops (Table 4). Including farmers who planted rice only in two consecutive seasons, $60 \%$ of farmers planted rice continuously. Some farmers have been planting NERICA continuously ever since they adopted it. It is more common, however, that after two to five seasons of continuous planting, farmers plant some non-rice crops for one to three seasons before coming back to rice in rotation. The list of non-rice crops in the rotation with rice is quite similar to the list of previous crops planted before rice (Haneishi et al., 2011a). The most popular crop in the rotation is maize, followed by sweet potato, either alone or both together. Another popular cropping pattern with rice in the study area is rice-vegetable-rice system, in which short maturing vegetables, most popularly a kind of leaf vegetable called bugga (Amaranthushybridus L.), is planted as an intercrop. Since these vegetables mature within a month, two crops of rice and two crops of vegetables can be harvested within a year.

\subsection{Current NERICA Production}

Unit yield of and land area planted to NERICA in current production in the study area are presented in this sub-section. The current production here refers to the 2009 1st and 2nd seasons and 2010 1st season, which, in terms of yield per ha, are not statistically different each other under similar rainfall conditions (Table 3 ). 


\subsubsection{Rice Yield}

Yield per ha for sample farmers in current NERICA production is summarized in Table 5 by farm size and by land tenure. It is remarkable that there was a large, statistically significant difference in average NERICA yields per ha between large and small farmers; $2.0 \mathrm{tha}^{-1}$ for the former and $3.3 \mathrm{tha}^{-1}$ for the latter. As expected (Hayami \& Otsuka, 1993), there is no significant difference in the NERICA yield between owned and leasehold areas.

The rice yield per ha of the 47 sample farmers are displayed in Figure 1 from the highest $\left(6.8 \mathrm{tha}^{-1}\right)$ to the lowest $\left(0.5 \mathrm{t} \mathrm{ha}^{-1}\right)$. The number of farmers who attained a yield higher than the average was 20, leaving 27 below the average. NERICA was high yielding on average, but the variance in yield was large and there were more farmers whose yield was less than the average.

\subsubsection{Area Planted}

Area planted to rice was on average 0.46 ha for large farmers and 0.27 ha for small farmers (Table 1). Remarkable is the fact that, although the area planted to rice was larger for large farmers than for small farmers, the ratio of large to small, $1.7(0.46 / 0.27)$, was far smaller than the same ratio for cultivated land area of 8.7 (6.1/0.7). This suggests that there are some limiting factors that inhibit a large scale cultivation of NERICA.The availability of land suited to grow NERICA could be an important limiting factor. Another factor suggested later in 3.4.4 of this paper is the highly labor intensive nature of NERICA technology.

\subsection{Cultivation Practices}

In this sub-section, we observe how much and in what ways farmers use factor inputs to produce rice. Production inputs for rice production can be classified in four groups; current inputs, labor, fixed capital, and land. Current inputs are those whose entire value is transferred to output and exhausted in one production cycle, such as seeds, fertilizers and chemicals. Land area planted to NERICA has been presented above, so let us observe the other three input groups.

\subsubsection{Seeds}

The majority of farmers reserved NERICA seeds from their own output in the previous seasons and $10 \%$ of them bought from fellow farmers in their villages or from NaCRRI (Table 6). There were four farmers who used seeds that were given to them. Of these, three obtained seeds from a NGO, which was promoting NERICA using a system of seed loan in that a certain amount of NERICA seeds is given to a farmer as a loan on condition that the farmer returns twice as much of seed from his/her output.

On average, the seeding rate of sample farmers was $110 \mathrm{~kg} \mathrm{ha}^{-1}$, more than twice as much as the recommended level of $50 \mathrm{~kg} \mathrm{ha}^{-1}\left(20 \mathrm{~kg} \mathrm{ac}^{-1}\right)$ (NaCRRI, undated). In particular, small farmers applied seeds significantly more than large farmers did. It is interesting to observe that the seeding rate of farmers who obtained NERICA seeds from NaCRRI and the NGO was closer to the recommended level. It also deserves to note that farmers who had once attended NERICA training offered by NaCRRI/JICA used significantly less seeds than those who had not. The seeding rate could be different for different methods of sowing. There are three methods of sowing; drill, dibble, and broadcast. The first two methods that allow straight-row planting are recommended practices (NaCRRI, undated). Except one farmer who adopted broadcasting, all the sample farmers adopted either the drill or the dibble method, mostly the latter. The high seeding rates in NERICA cultivation are not limited to the farmers in our study area. Kijima et al. (2011) found for a large sample of NERICA farmers in Central and Western districts that the average seeding rates of four groups of farmers ranged from 85 to $150 \mathrm{~kg} \mathrm{ha}^{-1}$. The average seeding rate of rainfed rice farmers in the entire country reported by Haneishi et al. (2011b) is around 90 $\mathrm{kg} \mathrm{ha}^{-1}$.

Observing such a high seeding rate by NERICA farmers, the question arising is why they tend to sow such a large amount of seed, far more than recommended level. A possible answer could be sought in farmers' sowing practices; they tend to place seeds too deep in soil, while land preparation, particularly harrowing, usually done manually with hoes, is not sufficient. Such practices result in a lower rate of germination, and hence a higher seeding rate. Another possible answer could be the poor quality of seed. Goto et al. (2011) reports that the germination rate of NERICA seed used by farmers could be as low as $50 \%$ or even lower. If the recommended rate is desirable and if the germination rate of farmers' seed is $50 \%$, they need to sow twice as much seed as the recommended level. The relatively lower seeding rates of farmers who obtained seeds from NaCRRI and the NGO may be due to the fact that the quality of their seeds was better than others. Likewise, farmers with NERICA training experience may be applying relatively less seed partly because they obtained knowledge on the recommended level during the training and partly because they were given, by the institutions that organized the training (e.g., NaCRRI/ JICA/ NGO), seeds of high quality, the offspring of which they are currently planting. In 
any case, the seeding rate had a positive, significant simple correlation with the yield per ha (Figure 2).

\subsubsection{Fertilizers}

The application of fertilizers by sample farmers is summarized in Table 7. It is often said that although the application of fertilizers, nitrogen fertilizers in particular, is of critical importance to attain higher yields from rice, farmers in sub-Saharan Africa use very little of them, mainly because of high prices of chemical fertilizers relative to rice (Otsuka \& Karilajan 2006). In our study area, 47\% of sample farmers applied some kind of fertilizers and the rate of application in terms of nitrogen applied was estimated at $11 \mathrm{~kg} \mathrm{ha}^{-1}$ for the total area planted to rice or $23 \mathrm{~kg} \mathrm{ha}^{-1}$ for the area with fertilizer application. Considering the risk and uncertainty inherent in upland rice cultivation, this level of fertilizer application could be called high. Indeed, comparing to the level of fertilizer application reported by Kijima et al. (2011), the fertilizer intensity of our sample farmers is several times higher. There was no difference in the share of famers using fertilizers between large and small farmers, but the fertilizer intensity differed significantly between them: Small farmers applied nearly three times more than large farmers did.

Farmers in the study area used both inorganic and organic fertilizers for NERICA. Except for cow dung that was self-supplied, all the fertilizers were purchased by the farmers. The most popular fertilizer was urea among inorganic fertilizers and chicken manure among organic fertilizers. Farmers who applied chicken manure usually bought it in terms of truck loads. With the assumed level of nutrient contents of $1 \%$, chicken manure was the largest source of nitrogen among those who applied fertilizers, followed by urea.

A positive impact of fertilizer application on NERICA yield is apparent in Figure 1 in which farmers who applied fertilizers are shown by a grey bar. There were some non-fertilizer-applying farmers who attained rice yield higher than the average. Similarly, there were some fertilizer-applying farmers whose yield level was lower than the average. However, it is clear that farmers with fertilizer application attained higher yields. The significant positive effect is more clearly seen in Figure 3, which depicts simple correlation between nitrogen intensity and rice yield for fertilizer users. The linear positive correlation between the variables is highly significant.

\subsubsection{Chemicals}

Chemicals that the sample farmers applied are classified in two groups, herbicides for weeding and insecticides and pesticides for insects and pests (Table 8). For the entire sample, 64\% of farmers applied some kind of chemicals. Of the two groups, herbicides were more popular. There were farmers, who applied insecticides and pesticides, but the number was small and all of them applied only one kind. For herbicides, not only the number of farmers who applied was large but quite a few of them applied both pre- and post-emergence herbicides together, e.g., Weedmaster and 2-4 D, indicating the importance of weeding in upland rice cultivation. Comparing large and small farmers, small farmers were stronger chemical users (73\%) than large farmers (47\%). For herbicides, $60 \%$ of small farmers applied pre-emergence herbicides and nearly $40 \%$ of them applied post-emergence herbicides. Reflecting on the lower percentage, the quantity of chemicals applied per ha was significantly lower for large farmers than for small farmers, if averaged over the rice planted areas including those of non-chemical appliers. If compared among chemical appliers, however, chemical intensity was significantly higher for large farmers than for small farmers.

The simple correlation coefficient between rice yield per ha and quantity of chemicals applied per ha is 0.16 but is not statistically significant. Instead, a significant negative correlation is found between the labor input for weeding per ha and the quantity of herbicides applied per ha (Figure 4). It is estimated that a 1 liter increase of herbicide application decreased weeding labor by 1.5 person-days. The average price of herbicides is UGX 13,000 (US\$ 6.20) liter $^{-1}$ for both Weedmaster and 2-4 D. If we take the regression equation above as showing a real causality, and if we assume that the average wage rate for hiring labor for weeding is UGX 900 (US\$0.43) hour $^{-1}$ and the working hours for weeding per day are 8 hours, an additional application of one liter of herbicide saves weeding labor worth UGX 10,800 (US\$ 5.10), which is nearly at the same level as, or a little lower than, the increase in herbicide input. This indicates that these two means of controlling weeds are more or less equivalent for farmers: Those whose opportunity cost of labor is high or who feel hiring labor is annoyance and troublesome would depend more on herbicides than otherwise.

\subsubsection{Labor}

It is not easy to obtain accurate data on labor inputs in upland crop cultivation by an interview survey based on farmers' recall, partly because often more than one crop are inter-cropped in the same fields and partly because the farmers' answer, when asked how many days or hours are spent for certain labor tasks, tends to be a lump 
sum for the number of persons worked and the length and duration of work. The former is not a problem in the study area, since rice is rarely inter-cropped with other crops. However, the latter creates a serious problem, particularly for labor tasks that are long lasting and are joined by many family members such as weeding and harvesting. In this study, unless the farmers' answers are clear and very specific, adjustments are made, except for bird scaring, adopting the following assumptions: (a) one week work consist of 5 working days, (b) one hour rest is taken for every four work hours, (c) family members with non-farm jobs can work one half of full time farm hands, (d) children attending schools can work one-third of full time farm hands, (d) no distinction is made for male-female labor. Table 9 summarizes farmers' labor use in NERICA production thus obtained.

NERICA cultivation in the study area begins with slashing by using hatchets widespread bushes and weeds on the fields where rice is to be planted, followed by plowing with hoes and land leveling with rakes. It is characteristic of upland rice cultivation in the study area that neither draft animal nor machine is used for land preparation so that the duration that these land preparation activities last is as long as one month or even longer. Pre-emergence herbicides and chicken manure, if used, are applied at the last stage of land preparation. All sample farmers except one sowed their seeds by digging straight lines one-way using planting forks. Farmers apply chemical fertilizers mostly by top dressing, not basal. Weeding is carried out manually, by uprooting weeds using hoes and hands, a few times within the first month after seeding. Scaring birds is a labor task necessary to avoid bird damages carried out for a month or more before harvesting. Rice is harvested by using knifes or hatchets and threshed usually by hand beating against a plastic mat spread on the ground. Threshed paddy is dried and winnowed in the fields and put into bags, which are more than 1.5 meters long, weighing on average $100 \mathrm{~kg} \mathrm{bag}^{-1}$, and carried to the farmer's house. The most popular means of transportation is motor cycle, followed by bicycle, on foot and lorry in that order. After being brought to the farmer's house, the paddy is further dried in the backyard, and is then ready to be milled or sold as paddy.

High intensity of labor use is a salient feature of upland rice cultivation in the study area. The total labor use for the sample farmers as a whole was 466 person-days ha ${ }^{-1}$. Even if labor use for bird scaring, which is intrinsically of a strong fixed-cost nature, is excluded, the total labor use was as much as 229 person-days ha $^{-1}$. Labor requirements are particularly high for land preparation, weeding, and harvesting and threshing. Such a high level of labor intensity in NERICA cultivation is not limited to the study area. It ranges from 250 to 410 person-days $\mathrm{ha}^{-1}$ in Central and Western districts (Kijima et al., 2011), and from 200 to 430 person-days ha ${ }^{-1}$ in a nation-wide upland rice farmer survey (Haneishi et al., 2011b).

It should be noted that the dependency on hired labor is high in NERICA cultivation. Of the total labor requirement, $40 \%$ were worked by hired labor including bird scaring, and nearly $50 \%$, if it is excluded. This high dependency on hired labor, regardless of farm size, is another salient feature of NERICA cultivation in the study area. For all the labor tasks listed in Table 9, the dependency rate on hired labor exceeded 30\%, except for drying and winnowing.

The labor intensity of small farmers was significantly higher than that of large farmers, for both including and excluding scaring birds, whereas the percentage share of hired labor was higher for small farmers than for large farmers, though not statistically significant. This anomaly may be explained by the difficulty of labor control. If farmers want to plant NERICA in a large tract of land, the high labor requirements make it necessary for them to hire a large number of hired workers, and the monitoring and enforcement of their labor works becomes increasingly hazardous as the area planted to NERICA increases. This must be a reason why the area planted to NERICA hardly exceeds 3 ac in the study area, rendering NERICA technology pro-small holders (Kijima et al., 2008; Haneishi et al., 2011a, 2011b).

\subsubsection{Fixed Capital and Other Inputs}

Fixed capital in farming are such assets as farm instruments, farm machines and draft animals, which farmers can use beyond one production cycle. The list of fixed capital used by farmers in rice cultivation in the study area is very short and simple. Included are mostly simple farm instruments, such as hoes, hatchets (panga), rakes, planting forks and harvesting knifes. Another farm asset in the list is plastic mats used when harvested paddy is threshed and dried. A relatively more important fixed capital is manual knapsack type chemical sprayers. The rental market for sprayers is well developed: Of the farmers who applied chemicals, $70 \%$ used sprayers they borrowed from other farmers at the average rental rate of UGX 1500 (US\$ 0.71) day ${ }^{-1}$. As explained, draft animals and farm machinery, such as hand tractors, are not used for rice cultivation in the study area. As the means of transporting threshed paddy from fields to farm houses, motor cycle, bicycle and lorry are used mostly as hired services.

The production inputs used for NERICA production explained thus far are nearly exhaustive, leaving few other 
inputs, except for sacks to store the threshed paddy.

\subsection{Determinants of Yield}

The results of yield function estimation are summarized in Table 10. As factor inputs, seeds $\left(\mathrm{kg} \mathrm{ha}^{-1}\right)$, nitrogen $\left(\mathrm{kg} \mathrm{ha}^{-1}\right)$, herbicides (liter ha ${ }^{-1}$ ) and labor excluding bird scaring (person-days ha $\mathrm{a}^{-1}$ ) are chosen for the estimation. Fixed capital is not included because it is difficult to single out the services attributable to rice production for most fixed capital assets that are used not only for rice but for other crop production. Other explanatory variables included in the estimation are small farmer dummy (small farmers $=1$ and large farmers $=0$ ), number of seasons rice has been continuously planted and NERICA training dummy (attended $=1$ and not attended $=0$ ). The parameters are estimated by applying ordinary least squares method for 43 observations: 4 observations are excluded because they are too influential and / or cause heteroscedasticity in the residuals. For all the three regression equations shown, the null hypothesis that the regression model has no omitted variable cannot be rejected and no multi-colinearity is detected. However, the null hypothesis of no heteroscedasticity cannot be rejected only for Regression III.

The estimation reveals that, among production inputs, seed, nitrogen and labor were positive and significant determinants of rice yield, while herbicide was not. The regression coefficient of seed is positive and significant at the 5\% level in Regression III, which is the best fitted with desirable statistical properties, showing that, ceteris paribus, a $1 \mathrm{~kg} \mathrm{ha}^{-1}$ of increase in seeds increases rice yield by about $8 \mathrm{~kg} \mathrm{ha}^{-1}$. Such a result is consistent with the finding by Haneishi et al. (2011b), which reports, using a country-wide survey of rainfed rice farmers, that a $1 \mathrm{~kg} \mathrm{ha}^{-1}$ increase in seeds results in an increase in the yield of $5-7 \mathrm{~kg} \mathrm{ha}^{-1}$, with the average seeding rate of about $90 \mathrm{~kg} \mathrm{ha}^{-1}$. These results indicate that it is necessary to reexamine whether the recommended seeding rate of $50 \mathrm{~kg} \mathrm{ha}^{-1}$ is appropriate, looking into the optimum level of seeding while taking into account the quality of seeds and the seeding method farmers are actually adopting.

The positive impact of nitrogen on rice yield is highly significant, though the regression coefficient of nitrogen $(\partial \mathrm{Y} / \partial \mathrm{N})$ decreases from $62 \mathrm{~kg} \mathrm{ha}^{-1}$ in Figure 3 to $46 \mathrm{~kg} \mathrm{ha}^{-1}$ in Regression III in Table 10, as other determinants of rice yield are accounted for. Even with this reduced level, which indicates that a $1 \mathrm{~kg} \mathrm{ha}^{-1}$ increase in nitrogen brings about a $46 \mathrm{~kg} \mathrm{ha}^{-1}$ of increase in rice yield, the coefficient is remarkably large, as the rate of response of rice to nitrogen in farmers' fields. For IR 8, the lowland rice cultivar heralded as "miracle rice" at the onset of rice Green Revolution in Asia, the yield response to nitrogen was about $60 \mathrm{~kg} \mathrm{ha}^{-1}$ for the nitrogen levels of 30 to $60 \mathrm{~kg} \mathrm{ha}^{-1}$ under ideal conditions in the experiment field at IRRI (De Datta et al., 1968; Peng et al., 1999). For NERICA grown under experimental conditions in the savannas of Nigeria, this rate of response was about $40 \mathrm{~kg}$ $\mathrm{ha}^{-1}$ for nitrogen levels of 30 to $60 \mathrm{~kg} \mathrm{ha}^{-1}$ for the best performing site and season (Kamara et al. 2010). Unlike in this study area, rainfed rice farmers in Uganda rarely use fertilizers, on average only about $1 \mathrm{~kg} \mathrm{ha}^{-1}$ of nitrogen, one-eleventh as compared to the level of our study area, and the yield response to nitrogen is estimated to be at most $17 \mathrm{~kg} \mathrm{ha}^{-1}$ (Haneishi et al., 2011b). The high response in the study area may partly be explained by farmers' heavy reliance on organic fertilizers.

The average price of urea in the study area was UGX 2,300 (US\$1.10) $\mathrm{kg}^{-1}$ and the average farm-gate price of paddy the sample farmers received was UGX 1,000 (US\$0.48) $\mathrm{kg}^{-1}$. Hence, the urea-paddy relative price ratio was 2.3, which was higher compared to that in Asian countries but much lower than that reported by Otsuka and Kalirajan (2006) as of around 2000. The price of nitrogen computed from this urea price is UGX 5,000 (US\$ 2.40) $\mathrm{kg}^{-1}$. If we take the regression coefficient (the marginal productivity) of nitrogen in Regression III, UGX 5,000 of additional input of nitrogen results in an increase in paddy output worth UGX 45,000 (US\$21.40). In the case of chicken manure, assuming a nitrogen content of $1 \%$, the nitrogen price is computed as UGX 11,200 (US\$ 5.30) $\mathrm{kg}^{-1}$. An additional nitrogen input by means of chicken manure generates an increase in paddy output, the value of which is still more than four times higher than the input cost. All this suggests that there should be a high incentive for farmers to apply fertilizers in NERICA cultivation. As long as the nitrogen-paddy relative price is not worsened, farmers' application of fertilizers will certainly increase in future. All this requires intensifying research on effective ways to apply fertilizers in order to realize the high fertilizer response of NERICA, which our sample farmers demonstrate.

The positive impact of total labor input on rice yield is also significant at the $1 \%$ level. The regression coefficient of labor in Regression III is $9.0 \mathrm{~kg} \mathrm{ha}^{-1}$ : An increase of one person-day in labor input brings about an increase in rice yield worth UGX 9,000 (US\$ 4.30). The average wage rate in the study area is around UGX 900 (US\$ 0.43 ) hour $^{-1}$. Therefore,the cost of a 1 day (8 hours) increase in labor input is worth UGX 7,200 (US\$ 3.40), which is roughly comparable with the increase in the value of rice output. NERICA cultivation in the study area is labor intensive, but the intensity is on average justified economically. The $95 \%$ confidence interval of the labor 
coefficient in Regression III being $2.3-13.8 \mathrm{~kg} \mathrm{ha}^{-1}$, however, many sample farmers would have applied labor input beyond the economically optimum level. Our finding in this regard suggests that it is important to increase labor productivity in NERICA cultivation, either through increasing rice yield for a given level of labor intensity or through devising appropriate technology to reduce labor needs for such arduous labor tasks as manual slashing, hand weeding and bird scaring.

An important result of the estimation is that small farmer dummy is not statistically significant. The large difference in rice yield per ha between small farmers and large farmers observed in Table 5 is explained by the difference in the intensity of production inputs between them: Small farmers attained higher yield than large farmers because they applied more inputs per unit of land than large farmers did. NERICA technology is pro-smallholders because its labor intensive nature and the lower opportunity cost of labor for small farmers should have made it possible for them to attain the higher input intensity than large farmers. The transaction cost inherent in hiring a large amount of labor would have reinforced the pro-smallholder nature.

Another factor that gives a significant impact on rice yield is the number of continuous plantings. Its negative coefficient indicates that the continuous planting of NERICA in upland fields reduces rice yield by $130 \mathrm{~kg} \mathrm{ha}^{-1}$ on average. Continuous planting without rotation or leaving fields fallow, ceteris paribus, depletes of soil nutrients resulting in lower yield. This is what is occurring in the study area with a relatively old history of NERICA planting. This also explains why the percentage of farmers who apply fertilizers is higher in the study area than in other rice growing upland and lowland areas in Uganda. It is also estimated that farmers who attended NERICA training attained rice yield higher by $630 \mathrm{~kg} \mathrm{ha}^{-1}$ than farmers without training experience. Such an impact of training may be compared to the study by Kijima et al. (2010) in which they found that one additional day of attendance to a 5-day training course in Sustainable Irrigated Agricultural Development (SIAD) Project by JICA in Eastern Uganda increased the yield of lowland paddy by $200 \mathrm{~kg} \mathrm{ha}^{-1}$.

\section{Conclusions}

We looked into actual farmers' cultivation practices of upland NERICA cultivation and the determinants of its yield, using data collected by a field survey conducted for farmers in Namulonge, the mother land of NERICA in Uganda and East Africa.

NERICA's high yield potential is realized in farmers' field. With adequate rainfall, farmers attained yield as high as $2.7 \mathrm{tha}^{-1}$ for the entire sample and $3.3 \mathrm{t} \mathrm{ha}^{-1}$ for small farmers. High input intensities characterize NERICA cultivation in the study area: Seeding rate more than twice as much as the recommended level of $50 \mathrm{~kg} \mathrm{ha}^{-1}$, fertilizer application as much as $11 \mathrm{~kg} \mathrm{ha}^{-1}$ in terms of nitrogen and chemical application as much as 5 liters ha ${ }^{-1}$, both quite high compared to other rice growing areas in Uganda, upland and lowland alike, and labor intensity as much as 466 person-days ha ${ }^{-1}$.

The estimation of yield function reveals the following points: The response of rice yield to nitrogen is as high as $46 \mathrm{~kg} \mathrm{ha}^{-1}$ of paddy per $1 \mathrm{~kg} \mathrm{ha}^{-1}$ of nitrogen applied; a $1 \mathrm{~kg} \mathrm{ha}^{-1}$ of increase in seeds applied increases rice yield by $8 \mathrm{~kg} \mathrm{ha}^{-1}$; and continuous planting of NERICA reduces its yield by $130 \mathrm{~kg} \mathrm{ha}^{-1}$ for every additional season of continuous planting. Though quite high, the labor intensity is on average in the range economically justifiable. The large difference in the unit yield of NERICA between large and small farmers is explained by small farmers' higher input intensities than large farmers', and it is the high labor requirement of NERICA that makes it a pro-smallholder technology.

\section{Acknowledgement}

We are grateful to M. Sako, J. Sakai, Lozio Aloysius Makesa, Nayiga Sylvia and Kefa Mwanje for their help rendered in the field survey of this research and Ryuuzo Nishimaki, Kunihiro Tokida and Akio Goto for their helpful comments on earlier drafts of this paper. Errors that possibly remain in this paper are all of the authors. Views and opinions expressed in this paper are of the authors, not necessarily of the institutions they belong to.

\section{References}

Balasubramanian, V., Sie, M., Hijman, R. J., \& Otsuka, K. (2007). Increasing rice production in sub- Saharan Africa: Challenges and opportunities. Advances in Agronomy, 94, 55-133. http://dx.doi.org/10.1016/S0065-2113(06)94002-4

Batungi, N. (2008). Land reform in Uganda: Towards a harmonized tenure system. Fountain Publisher, Kampala.

De, Datta, S. K., Tauro, A. C., \& Balaoing, S. N. (1968). Effect of plant type and nitrogen level on growth characteristics and grain yield of indica rice in the tropics. Agronomy Journal, 60, 643-647. 
Fujiie, H., Maruyama, A., Fujiie, M., Takagaki, M., \& Kikuchi, M. (2010). Determinants of NERICA adoption in Uganda based on duration analysis. Tropical Agriculture and Development, 54, 17-24.

Goto, A., Tsuboi, T., Asea, G., Takagaki, M., \& Kikuchi, M. (2011). An Assessment of quality of upland rice seeds in Uganda. An internal report of NaCRRI-JICA NERICA Project, Namulonge, Uganda.

Hayami, Y., \& Otsuka, K. (1993). The economics of contract choice: An Agrarian Perspective. Clarendon Press, Oxford.

Haneishi, Y., Miyamoto, K., Matsumoto, S., Okello, S. E., Asea, G., Tsuboi, T., Maruyama, A., Takagaki, M., \& Kikuchi, M. (2011a). Integration of NERICA into an upland farming system and its impacts on farmers' income: A case study in Namulonge, Uganda. An internal report of NaCRRI-JICA NERICA Project, Namulonge, Uganda.

Haneishi, Y., Maruyama, A., Asea, G., Okello, S. E., Tsuboi, T., Takagaki, M., \& Kikuchi., M. (2011b). Exploration of rainfed rice farming in Uganda based on a nationwide survey: Regionality, varieties and yield. $A n$ internal report of NaCRRI-JICA NERICA Project. Namulonge, Uganda.

Kamara, A. Y., Ekeleme, F., Omoigui, L. O., Oikeh, S. O., Chikoye, D., \& Tegbaru, A. (2010). Response of upland rice cultivars to nitrogen fertilizer in the savannas of Nigeria. Agronomy Journal, 102, 333-339. http://dx.doi.org/10.21.34/agronj2009.02.38

Kaneda, C. (2007). Breeding and dissemination efforts of "NERICA", (1) to (4). Japanese Journal of Tropical Agriculture, 51, 1-4, 41-45, 79-83, 145-151.

Kijima, Y., Sserunkuuma, D., \& Otsuka, K. (2006). How revolutionary is the 'NERICA revolution'?: Evidence from Uganda. Developing Economies, 44, 252-67. http://dx.doi.org/10.1111/j.1746-1049.2006.00016.x

Kijima, Y., Otsuka, K., \& Sserunkuuma, D. (2008). Assessing the impact of NERICA on income and poverty in central and western Uganda. Agricultural Economics, 38, 327-337.

Kijima, Y., Ito, Y., \& Otsuka, K. (2010). On the possibility of a lowland rice Green Revolution in sub-Saharan Africa: Evidence from the Sustainable Irrigated Agricultural Development (SIAD) Project in Eastern Uganda. JICA-RI Working Paper, 25, JICA Research Institute, Tokyo.

Kijima, Y., Otsuka, K., \& Sserunkuuma, D. (2011). An inquiry into constraints on a Green Revolution in sub-Saharan Africa: The case of NERICA rice in Uganda. World Development, 39, 77-86.

National Crops Resources Research Institute (NaCRRI). (Undated).Rice cultivation handbook. NERICA Promotion Project, National Crops Resources Research Institute, Namulonge, Uganda.

Otsuka, K., \& Kalirajan, K. (2006). Rice Green Revolution in Asia and its transferability to Africa. Developing Economies, 44, 107-122. http://dx.doi.org/10.1111/j.1746-1049.2006.00009.x

Peng, S., Cassman, K. G., Virmani, S. S., Sheehy, J., \& Khush., G. S. (1999). Yield potential trends of tropical rice since the release of IR8 and the challenge of increasing rice yield potential. Crop Science, 39, 1552-1559.

Sako, M., Miyamoto, K., Sakai, J., Matsumoto, S., Goto, A., \& Kikuchi, M. (2010). Adoption of NERICA in villages around Namulonge: Summary of village chairperson survey. An internal report of NaCRRI-JICA NERICA Project. Namulonge, Uganda.

Somado, E. A., Guei, R. G., \& Keya, S. O. (2008). NERICA: the New Rice for Africa - a Compendium. Africa Rice Center, Cotonou, Benin.

West Africa Rice Development Association (WARDA). (2001). NERICA: Rice for life. West Africa Rice Development Association, Bouaké, Côte d'Ivoire.

West Africa Rice Development Association (WARDA). (2002). Annual Report 2001-2002. West Africa Rice Development Association, Bouaké, Côte d'Ivoire. 
Table 1. Household characteristics of sample famers, 2010

\begin{tabular}{|c|c|c|c|c|c|c|c|}
\hline & \multicolumn{2}{|c|}{ All } & \multicolumn{2}{|c|}{ Large farmers } & \multicolumn{2}{|c|}{ Small farmers } & \multirow{2}{*}{ Difference $^{a}$} \\
\hline & AV. & S.D. & $\mathrm{AV}$. & S.D. & AV. & S.D. & \\
\hline Head age (yrs) & 43.1 & 10.4 & 45.5 & 11.2 & 41.7 & 9.8 & ns \\
\hline Head education (yrs) & 6.3 & 4.1 & 7.8 & 5.1 & 2.8 & 3.3 & $*$ \\
\hline Female-headed $(\%)$ & 12.8 & & 0 & & 20.0 & & $* *$ \\
\hline Head with non-farm occupation $(\%)$ & 31.9 & & 52.9 & & 20.0 & & $* *$ \\
\hline No. of household members & 7.0 & 2.8 & 8.5 & 2.6 & 6.1 & 2.5 & $* * *$ \\
\hline No. of members age 10 and above & 4.4 & 2.1 & 5.4 & 2.0 & 3.8 & 2.0 & $* * *$ \\
\hline Member of farmers' group (\%) & 46.8 & & 76.5 & & 30.0 & & $* * *$ \\
\hline Attended NERICA training (\%) & 51.1 & & 82.4 & & 33.3 & & $* * *$ \\
\hline Cultivated land area (ha farm ${ }^{-1}$ ) & 2.7 & 4.8 & 6.1 & 6.8 & 0.7 & 0.4 & $* * *$ \\
\hline Land area planted to rice (ha farm ${ }^{-1}$ ) & 0.34 & 0.25 & 0.46 & 0.32 & 0.27 & 0.16 & $* * *$ \\
\hline With leased-in area $(\%)$ & 27.7 & & 17.6 & & 33.3 & & ns \\
\hline
\end{tabular}

a. Difference between large and small farmers.

Table 2. Rice yield and varieties planted by sample farmers, 2006 - 10

\begin{tabular}{|c|c|c|c|c|c|c|c|c|c|}
\hline & \multicolumn{2}{|c|}{2006} & \multicolumn{2}{|c|}{2007} & \multicolumn{2}{|c|}{2008} & \multicolumn{2}{|c|}{2009} & 2010 \\
\hline & $1 \mathrm{st}$ & $2 \mathrm{nd}$ & $1 \mathrm{st}$ & $2 \mathrm{nd}$ & $1 \mathrm{st}$ & $2 \mathrm{nd}$ & $1 \mathrm{st}$ & $2 \mathrm{nd}$ & $1 \mathrm{st}$ \\
\hline No. of farmers reporting & 10 & 16 & 13 & 11 & 14 & 15 & 25 & 34 & 36 \\
\hline Area planted per farm (ha) & 0.41 & 0.40 & 0.49 & 0.41 & 0.40 & 0.48 & 0.28 & 0.32 & 0.34 \\
\hline Yield $\left(\mathrm{t} \mathrm{ac}^{-1}\right)$ & 1.50 & 0.91 & 1.19 & 1.05 & 1.04 & 1.30 & 1.24 & 1.11 & 1.07 \\
\hline Yield $\left(\mathrm{t} \mathrm{ha}^{-1}\right)$ & 3.71 & 2.24 & 2.94 & 2.60 & 2.58 & 3.22 & 3.07 & 2.74 & 2.65 \\
\hline Yield variation (CV: \%) & $83 \%$ & $86 \%$ & $75 \%$ & $73 \%$ & $75 \%$ & $84 \%$ & $75 \%$ & $64 \%$ & $65 \%$ \\
\hline Variety planted (no.) a.: & & & & & & & & & \\
\hline NERICA 1 & & & & & & & & & 1 \\
\hline NERICA 4 & 6 & 6 & 6 & 5 & 8 & 13 & 24 & 31 & 34 \\
\hline NERICA 10 & & & & & & & 1 & & 1 \\
\hline Suparica & & 1 & 1 & 1 & & & & 2 & 1 \\
\hline Non-NERICA (upland) & & 2 & 3 & 1 & & & & & \\
\hline Mixed seeds & & 1 & & 1 & 1 & & & & 1 \\
\hline Kaiso & & & & & & & & & 1 \\
\hline Unknown & 4 & 6 & 3 & 3 & 5 & 2 & 3 & 2 & 0 \\
\hline
\end{tabular}

a. Some farmers planted more than one variety in a season.

Table 3. Rice yield per ha and rainfall by year and season, 2006-10

\begin{tabular}{lcc}
\hline & Yield $\left(\mathrm{t} \mathrm{ha}^{-1}\right)$ & Rainfall $\left(\mathrm{mm} \mathrm{year}^{-1}\right)^{\mathrm{c}}$ \\
\hline Year $^{\mathrm{a}}$ : & 2.8 & \\
2006 & 2.8 & 1249 \\
2007 & 2.9 & 1185 \\
2008 & 2.9 & 1285 \\
2009 & 2.7 & 1003 \\
2010 & & 733 \\
Season $^{\mathrm{b}}$ : & 2.8 & \\
First season & 2.7 & 559 \\
Second season & & 665 \\
\hline
\end{tabular}

a. Yield is the average over 1 st and 2 nd seasons. No statistical difference in yield among the years.

b. Yield is the averages over 2006-10.No statistical difference in yield between the seasons.

c. The rainfall of 2010 is of the first half. The rainfall for seasons are the average over 2006-10. 
Table 4. Number of farmers by degree of continuous planting and by previous crop, 2009-10

\begin{tabular}{ccclcc}
\hline $\begin{array}{c}\text { No. of seasons rice was } \\
\text { continuously planted }^{\text {a }}\end{array}$ & no. & $\mathbf{( \% )}$ & Previous crops before rice & no. & $(\%)$ \\
\hline 0 & 19 & $(40)$ & Maize + sweet potato & 7 & $(37)$ \\
1 & 15 & $(32)$ & Maize + cassava & 1 & $(5)$ \\
2 & 4 & $(9)$ & Maize & 1 & $(5)$ \\
3 & 4 & $(9)$ & Sweet potato + plantain & 1 & $(5)$ \\
4 & 1 & $(2)$ & Sweet potato & 3 & $(16)$ \\
5 & 0 & $(0)$ & Vegetables & 2 & $(11)$ \\
6 & 0 & $(0)$ & Yam & 1 & $(5)$ \\
7 & 2 & $(4)$ & Fallow & 1 & $(5)$ \\
8 & 2 & $(4)$ & Virgin land & 2 & $(11)$ \\
Total & 47 & $(100)$ & Total & 19 & $(100)$ \\
\hline
\end{tabular}

a. 0 season means rice was planted after other crops, after fallow, or on virgin land.

b. Two crops, e.g., maize + sweet potato, means that these crops were planted just before rice.

Table 5. Rice yield per ha by farm size and by land tenure, 2009-10

\begin{tabular}{|c|c|c|c|}
\hline & \multicolumn{2}{|c|}{ No. of farmers } & \multirow{2}{*}{$\frac{\text { Yield }}{\mathrm{kg} \mathrm{ha}^{-1}}$} \\
\hline & no. & $(\%)$ & \\
\hline All & 47 & (100) & 2,652 \\
\hline \multicolumn{4}{|l|}{ Farm size: } \\
\hline Large farmer & 17 & (36) & 2,045 \\
\hline Small farmer & 30 & (64) & 3,253 \\
\hline Difference & & & $* *$ \\
\hline \multicolumn{4}{|l|}{ Land tenure: } \\
\hline Owned area & 34 & (72) & 2,613 \\
\hline Leasehold area $^{a}$ & 13 & (28) & 2,746 \\
\hline Difference & & & ns \\
\hline
\end{tabular}

a. Include owner-cum-tenant farmers. In terms of area, the share of leasehold land was $24 \%$ of the total land planted to rice.

Table 6. Number of farmers by seed source and seeding rate, 2009-10

\begin{tabular}{|c|c|c|c|c|c|c|c|c|c|c|}
\hline \multirow[b]{2}{*}{ Seed source } & \multicolumn{3}{|c|}{ All } & \multicolumn{3}{|c|}{ Large farmer } & \multicolumn{3}{|c|}{ Small farmer } & \multirow[b]{2}{*}{$\begin{array}{c}\text { Difference } \\
\text { between large and } \\
\text { small }\end{array}$} \\
\hline & No. & $(\%)$ & $\begin{array}{l}\text { Seeding } \\
\text { rate } \\
\left(\mathrm{kg} \mathrm{ha}^{-1}\right)\end{array}$ & No. & $(\%)$ & $\begin{array}{l}\text { Seeding } \\
\text { rate } \\
\left(\mathrm{kg} \mathrm{ha}^{-1}\right)\end{array}$ & No. & $(\%)$ & $\begin{array}{l}\text { Seeding } \\
\text { rate } \\
\left(\mathrm{kg} \mathrm{ha}^{-1}\right)\end{array}$ & \\
\hline From own produce & 40 & $(85)$ & 113 & 14 & $(82)$ & 84 & 26 & (87) & 129 & \\
\hline \multicolumn{11}{|l|}{ Bought: } \\
\hline From farmer & 3 & (6) & 133 & & & & 3 & $(10)$ & 133 & \\
\hline From NaCRRI & 2 & (4) & 74 & 2 & (12) & 74 & & & & \\
\hline \multicolumn{11}{|l|}{ Given: } \\
\hline By NGO & 3 & (6) & 76 & 2 & (12) & 77 & 1 & (3) & 74 & \\
\hline By neighboring farmer & 1 & $(2)$ & 49 & & & & 1 & (3) & 49 & \\
\hline Total & 49 & (104) & 110 & 18 & $(106)$ & 81 & 31 & (103) & 126 & \\
\hline Total no. of samples & 47 & $(100)$ & & 17 & $(100)$ & & 30 & $(100)$ & & \\
\hline \multicolumn{11}{|l|}{$\begin{array}{l}\text { Seeding rate (kg } \\
\left.\mathrm{ha}^{-1}\right) \text { : }\end{array}$} \\
\hline All & 47 & & 110 & 17 & & 81 & 30 & & 126 & $* * *$ \\
\hline With training & 24 & & 89 & 14 & & 82 & 10 & & 98 & ns \\
\hline Without training & 23 & & 132 & 3 & & 77 & 20 & & 141 & $* * *$ \\
\hline $\begin{array}{l}\text { Difference between } \\
\text { with } \\
\text { and without training }\end{array}$ & & & $* * *$ & & & ns & & & $* * *$ & \\
\hline
\end{tabular}


Table 7. Number of NERICA farmers who apply fertilizers and quantity applied, 2009-10

\begin{tabular}{|c|c|c|c|c|c|c|c|c|c|c|}
\hline & \multirow{3}{*}{ Unit } & \multicolumn{3}{|c|}{ All } & \multicolumn{3}{|c|}{ Large famer } & \multicolumn{3}{|c|}{ Small farmer } \\
\hline & & \multicolumn{2}{|c|}{$\begin{array}{l}\text { No. of } \\
\text { farmers } \\
\text { applied }\end{array}$} & \multirow{2}{*}{$\begin{array}{l}\text { Quantity } \\
\text { per } \\
\text { applied } \\
\text { area } \\
\text { unit ha }^{-1} \\
\end{array}$} & \multicolumn{2}{|c|}{$\begin{array}{l}\text { No. of } \\
\text { farmers } \\
\text { applied }\end{array}$} & \multirow{2}{*}{$\begin{array}{l}\text { Quantity } \\
\text { per } \\
\text { applied } \\
\text { area } \\
\text { unit ha }^{-1} \\
\end{array}$} & \multicolumn{2}{|c|}{$\begin{array}{l}\text { No. of } \\
\text { farmers } \\
\text { applied }\end{array}$} & \multirow{2}{*}{$\begin{array}{l}\text { Quantity per } \\
\text { applied area } \\
\text { unit ha }^{-1}\end{array}$} \\
\hline & & No. & $(\%)$ & & No. & $(\%)$ & & No. & $(\%)$ & \\
\hline \multicolumn{11}{|l|}{ Inorganic fertilizer: } \\
\hline Urea & $\mathrm{kg}$ & 9 & (19) & 33 & 3 & $(18)$ & 32 & 6 & $(20)$ & 34 \\
\hline NPK & $\mathrm{kg}$ & 2 & (4) & 12 & 2 & (12) & 12 & & $(0)$ & \\
\hline DAP & $\mathrm{kg}$ & 1 & (2) & 49 & 1 & $(6)$ & 49 & & (0) & \\
\hline Rapid draw & liter & 1 & (2) & 4 & & $(0)$ & & 1 & (3) & 10 \\
\hline \multicolumn{11}{|l|}{ Organic fertilizer: } \\
\hline Chicken manure & ton & 9 & (19) & 3.6 & 1 & (6) & 3.3 & 8 & $(27)$ & 3.7 \\
\hline Cow dung & $\mathrm{kg}$ & 1 & $(2)$ & 49 & 1 & (6) & 49 & & $(0)$ & \\
\hline Super Green & $\mathrm{kg}$ & 1 & $(2)$ & 2 & 1 & (6) & 2 & & $(0)$ & \\
\hline Total & & 24 & $(51)$ & & 9 & $(53)$ & & 15 & $(50)$ & \\
\hline No. reporting & & 47 & $(100)$ & & 17 & $(100)$ & & 30 & $(100)$ & \\
\hline No. applying fertilizer & & 22 & $(47)$ & & 8 & $(47)$ & & 14 & $(47)$ & \\
\hline $\begin{array}{l}\text { Nitrogen applied (for } \\
\text { entire rice planted area) } \\
\left(\mathrm{kg} \mathrm{ha}^{-1}\right)^{\mathrm{a}}\end{array}$ & & \multicolumn{3}{|c|}{11} & \multicolumn{3}{|c|}{5} & \multicolumn{2}{|c|}{14} & $* * b$ \\
\hline $\begin{array}{l}\text { Nitrogen applied (for } \\
\text { area with fertilizer } \\
\text { application) }\left(\mathrm{kg} \mathrm{ha}^{-1}\right)\end{array}$ & & \multicolumn{3}{|c|}{23} & \multicolumn{2}{|c|}{11} & & \multicolumn{2}{|c|}{30} & $* * * \mathrm{~b}$ \\
\hline
\end{tabular}

a. The rates of nitrogen content assumed are as follows: Urea $=46 \%, \mathrm{NPK}=17 \%, \mathrm{DAP}=18 \%$, Rapid draw $=10 \%$, chicken manure $=1 \%$, cow dung $=0.5 \%$, Super green $=2.5 \%$.

b. For difference between large and small farmers.

Table 8 . Number of NERICA farmers who apply chemicals and quantity applied, 2009-10

\begin{tabular}{|c|c|c|c|c|c|c|c|c|c|}
\hline & \multicolumn{3}{|c|}{ All } & \multicolumn{3}{|c|}{ Large farmer } & \multicolumn{3}{|c|}{ Small farmer } \\
\hline & \multicolumn{2}{|c|}{$\begin{array}{l}\text { No. of } \\
\text { farmers } \\
\text { adopted }\end{array}$} & \multirow{2}{*}{$\begin{array}{l}\text { Quantity } \\
\text { per ha of } \\
\text { applied } \\
\text { area } \\
\text { liter ha }^{-1}\end{array}$} & \multicolumn{2}{|c|}{$\begin{array}{l}\text { No. of } \\
\text { farmers } \\
\text { adopted }\end{array}$} & \multirow{2}{*}{$\begin{array}{l}\text { Quantity } \\
\text { per ha of } \\
\text { applied } \\
\text { area } \\
\text { liter ha }^{-1}\end{array}$} & \multicolumn{2}{|c|}{$\begin{array}{l}\text { No. of } \\
\text { farmers } \\
\text { adopted }\end{array}$} & \multirow{2}{*}{$\begin{array}{l}\text { Quantity } \\
\text { per ha of } \\
\text { applied } \\
\text { area } \\
\text { liter ha }^{-1}\end{array}$} \\
\hline & No. & $(\%)$ & & No. & $(\%)$ & & No. & $(\%)$ & \\
\hline \multicolumn{10}{|l|}{ Herbicide: } \\
\hline \multicolumn{10}{|l|}{ Pre-emergence: } \\
\hline Weedmaster & 21 & $(45)$ & 7.2 & 5 & (29) & 3.5 & 16 & $(53)$ & 9.6 \\
\hline Others & 2 & $(4)$ & 6.6 & & & & 2 & $(7)$ & 6.6 \\
\hline \multicolumn{10}{|l|}{ Post emergence: } \\
\hline $2-4 \mathrm{D}$ & 12 & $(26)$ & 4.7 & 4 & (24) & 4.9 & 8 & (27) & 4.3 \\
\hline Butanile 70 & 4 & (9) & 5.5 & 1 & $(6)$ & 2.5 & 3 & (10) & 6.4 \\
\hline Total & 39 & (83) & & 10 & (59) & & 29 & (97) & \\
\hline Insecticide \& pesticide & 7 & (15) & 3.2 & 1 & $(6)$ & 3.7 & 6 & $(20)$ & 3.1 \\
\hline Total & 46 & $(98)$ & & 11 & $(65)$ & & 35 & (117) & \\
\hline No. reporting & 47 & $(100)$ & & 17 & $(100)$ & & 30 & $(100)$ & \\
\hline No. applying chemicals & 30 & $(64)$ & & 8 & $(47)$ & & 22 & $(73)$ & \\
\hline $\begin{array}{l}\text { Chemicals applied per ha } \\
\text { (for entire rice planted } \\
\text { area) (liter ha } \mathrm{ha}^{-1} \text { ) }\end{array}$ & \multicolumn{3}{|c|}{5.2} & \multicolumn{3}{|c|}{4.0} & \multicolumn{2}{|c|}{5.8} & $* * *$ a \\
\hline $\begin{array}{l}\text { Chemical applied per ha } \\
\text { (for area with chemical } \\
\text { application) (liter ha-1) }\end{array}$ & \multicolumn{2}{|c|}{8.1} & & \multicolumn{2}{|c|}{8.5} & & \multicolumn{2}{|c|}{8.0} & $* * *$ a \\
\hline
\end{tabular}

a. For difference between large and small farmers. 
Table 9. Labor use in rice production, 2009-10 ${ }^{\mathrm{a}}$

\begin{tabular}{|c|c|c|}
\hline & $\begin{array}{c}\text { Total } \\
{\text { Person-days } \mathrm{ha}^{-1}}^{-1}\end{array}$ & $\begin{array}{c}\% \text { of hired labor } \\
(\%)\end{array}$ \\
\hline \multicolumn{3}{|l|}{ All: } \\
\hline \multicolumn{3}{|l|}{ Land preparation ${ }^{\mathrm{b}}$ : } \\
\hline Slashing & 19 & $(71)$ \\
\hline Plowing & 32 & $(58)$ \\
\hline Leveling & 18 & (44) \\
\hline Herbicide application & 2 & $(46)$ \\
\hline Total & 70 & (57) \\
\hline Seeding ${ }^{c}$ & 28 & (46) \\
\hline Fertilizer and chemical application & 3 & (46) \\
\hline Weeding & 64 & (42) \\
\hline Harvesting and threshing & 55 & $(53)$ \\
\hline Drying and winnowing & 6 & (18) \\
\hline Transporting paddy to farm-gate & 2 & (30) \\
\hline Scaring birds & 236 & $(32)$ \\
\hline Total $^{\mathrm{e}}$ & 466 & (40) \\
\hline Total excluding scaring birds & 229 & (49) \\
\hline \multicolumn{3}{|l|}{ Large farmers: } \\
\hline Total & 394 & $(35)$ \\
\hline Total excluding scaring birds & 201 & (46) \\
\hline \multicolumn{3}{|l|}{ Small farmers: } \\
\hline Total & 536 & $(44)$ \\
\hline Total excluding scaring birds & 257 & $(51)$ \\
\hline \multicolumn{3}{|l|}{ Difference: } \\
\hline Total & $* * *$ & ns \\
\hline Total excluding scaring birds & $* * *$ & ns \\
\hline
\end{tabular}

a. One person-day $=8$ hours day ${ }^{-1}$.

b. Some farmers reported labor use for all or more than one land preparation tasks together.

c. All farmers adopted drill-lined seeding method, except one who adopted broadcasting.

d. Some farmers reported labor use for drying and winnowing in harvesting and threshing.

e. Total labor use from land preparation to hauling paddy produce to farm-gate.

Table 10. Regression estimates of rice yield function ${ }^{\text {a }}$

\begin{tabular}{|c|c|c|c|c|c|c|}
\hline & \multicolumn{2}{|c|}{$[\mathrm{I}]$} & \multicolumn{2}{|c|}{$[$ II ] } & \multicolumn{2}{|c|}{ [ III ] } \\
\hline & Coeff. & Prob. & Coeff. & Prob. & Coeff. & Prob. \\
\hline \multicolumn{7}{|l|}{ Inputs: } \\
\hline Seed & 5.04 & 0.231 & 7.82 & 0.086 & 8.29 & 0.047 \\
\hline Nitrogen & 48.29 & 0.000 & 49.73 & 0.000 & 46.40 & 0.000 \\
\hline Labor & 6.99 & 0.027 & 7.50 & 0.017 & 8.06 & 0.007 \\
\hline Herbicide & -4.48 & 0.831 & 2.83 & 0.893 & 8.95 & 0.652 \\
\hline \multicolumn{7}{|l|}{ Other variables: } \\
\hline Small farmer (dummy) & & & -541 & 0.127 & & \\
\hline No. of continuous planting & & & & & -129 & 0.035 \\
\hline NERICA training (dummy) & & & & & 635 & 0.034 \\
\hline Constant & -287 & 0.649 & -409 & 0.513 & -1022 & 0.113 \\
\hline $\mathrm{R}^{2}$ (adjusted) & \multicolumn{2}{|c|}{0.619} & \multicolumn{2}{|c|}{0.633} & \multicolumn{2}{|c|}{0.681} \\
\hline Degree of freedom & \multicolumn{2}{|c|}{38} & \multicolumn{2}{|c|}{37} & \multicolumn{2}{|c|}{36} \\
\hline $\mathrm{B}-\mathrm{P} / \mathrm{C}-\mathrm{W}$ test $^{\mathrm{b}}$ & 5.14 & 0.023 & 5.62 & 0.018 & 0.34 & 0.558 \\
\hline Ramsey RESET test ${ }^{c}$ & 0.17 & 0.914 & 0.44 & 0.727 & 0.56 & 0.645 \\
\hline Mean V I F ${ }^{\mathrm{d}}$ & \multicolumn{2}{|c|}{1.43} & \multicolumn{2}{|c|}{1.54} & \multicolumn{2}{|c|}{1.42} \\
\hline
\end{tabular}

a. For 43 farmers, excluding 4 observations that cause heteroscedasticity in the residuals and / or are too influential.

b. Test for null hypothesis of no heteroskedasticity.

c. Test for null hypothesis that the model has no omitted variable.

d. Test for multi-colinearity: If the value of VIF is less than 10, no multi-colinearity exists. 


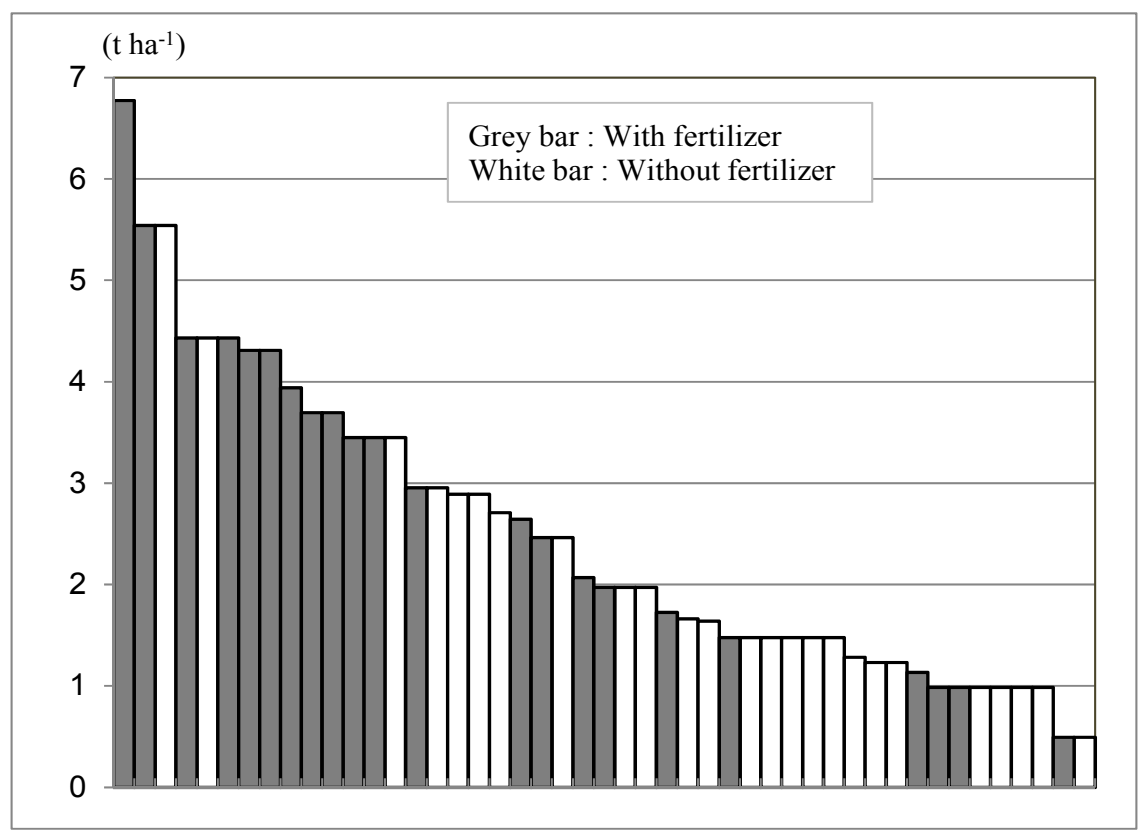

Figure 1. Rice yield per ha by farmer with and without fertilizer application, 2009-10

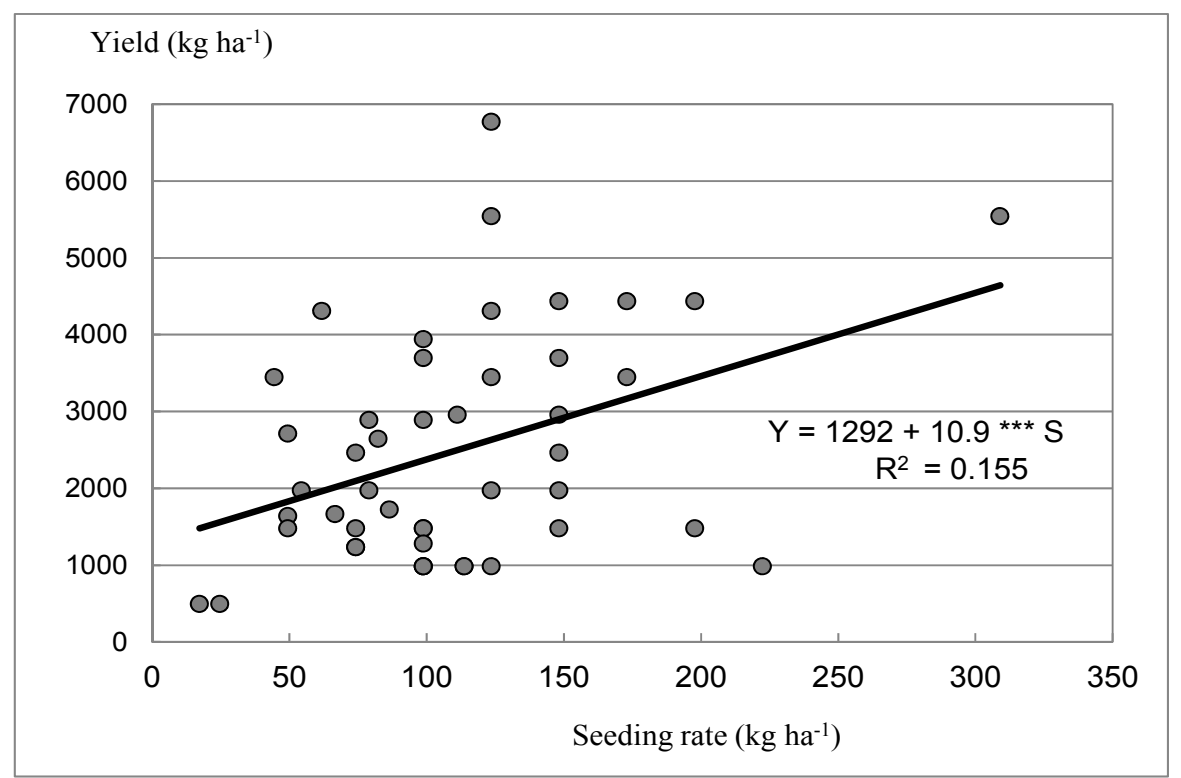

Figure 2. Rice yield and seeding rate, 2009-10 


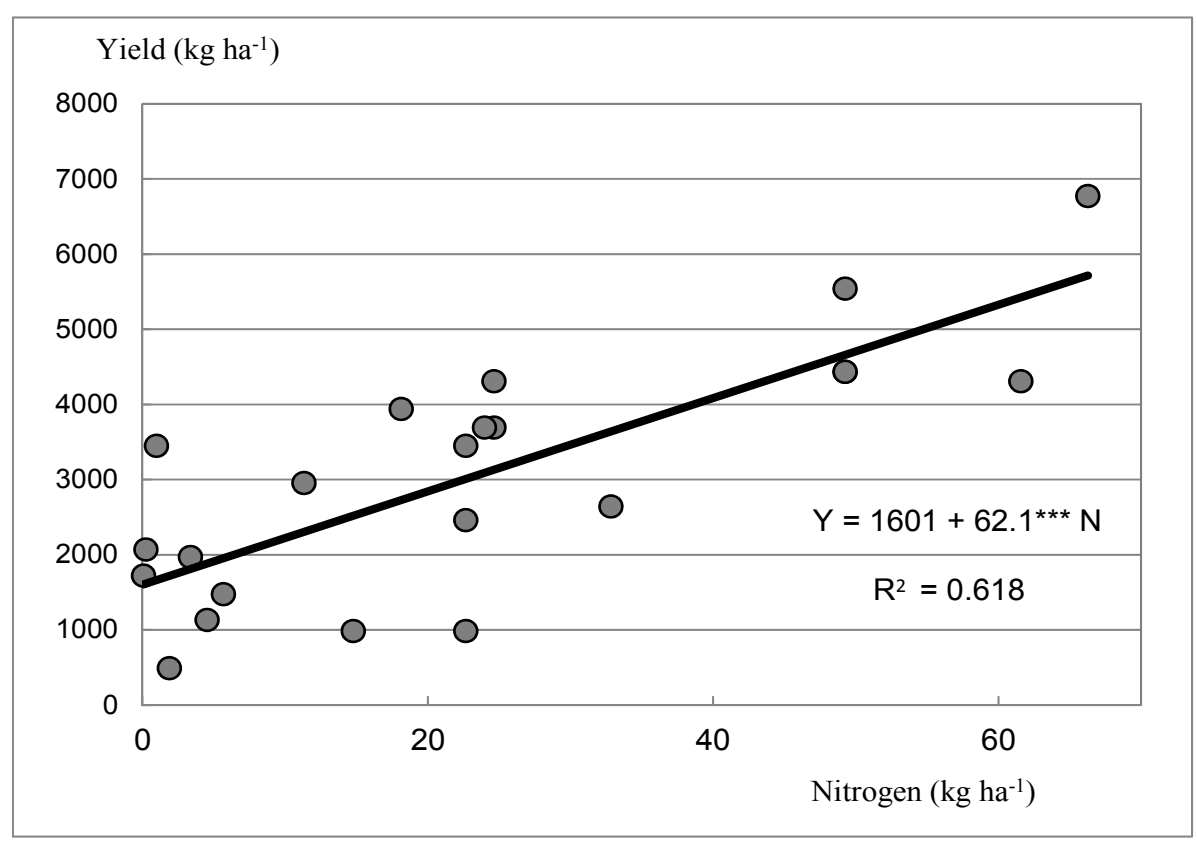

Figure 3. Rice yield and nitrogen use for farmers applying fertilizers, 2009-10

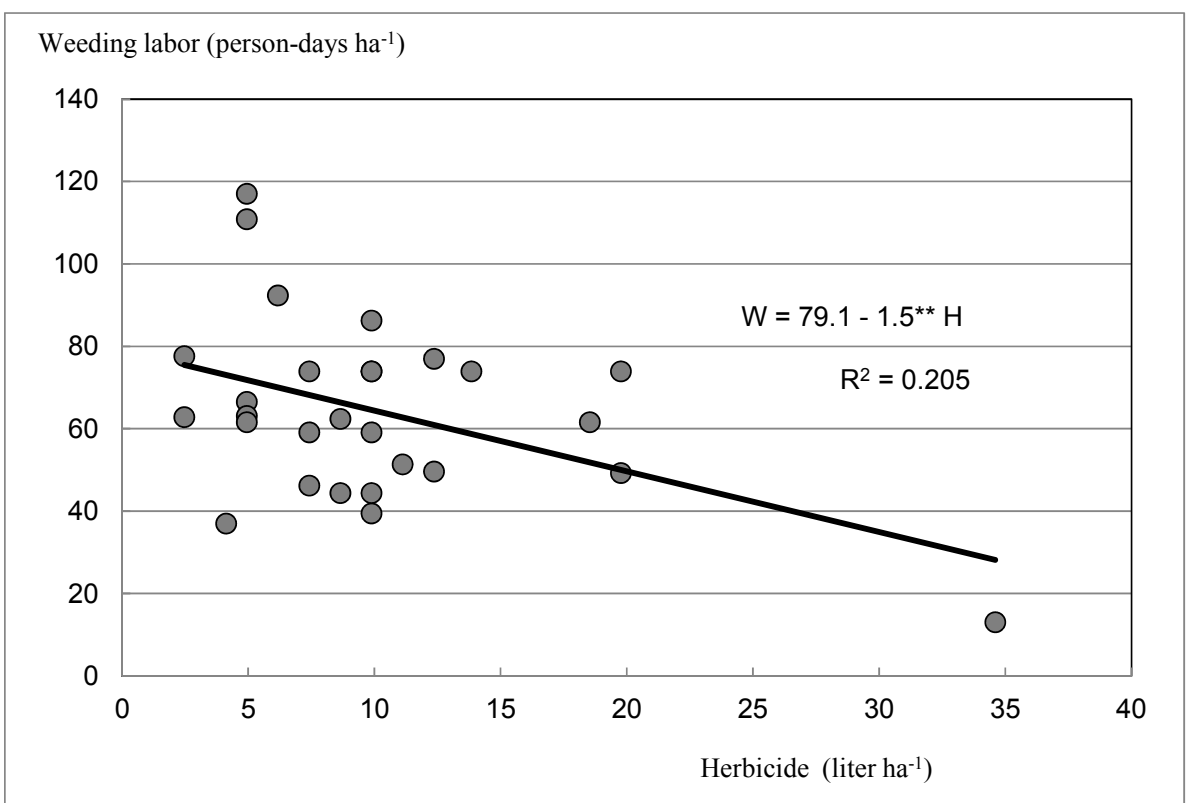

Figure 4. Weeding labor and herbicides use for farmers applying herbicides, 2009-10 